\title{
Derivatization Strategies for the Detection of Triamcinolone Acetonide in Cartilage by Using Matrix- Assisted Laser Desorption/lonization Mass Spectrometry Imaging
}

Citation for published version (APA):

Barre, F. P. Y., Flinders, B., Garcia, J. P., Jansen, I., Huizing, L. R. S., Porta, T., Creemers, L. B., Heeren, R. M. A., \& Cillero-Pastor, B. (2016). Derivatization Strategies for the Detection of Triamcinolone Acetonide in Cartilage by Using Matrix-Assisted Laser Desorption/lonization Mass Spectrometry Imaging. Analytical Chemistry, 88(24), 12051-12059. https://doi.org/10.1021/acs.analchem.6b02491

Document status and date:

Published: 20/12/2016

DOI:

10.1021/acs.analchem.6b02491

Document Version:

Accepted author manuscript (Peer reviewed / editorial board version)

Document license:

CC BY-NC-ND

Please check the document version of this publication:

- A submitted manuscript is the version of the article upon submission and before peer-review. There can be important differences between the submitted version and the official published version of record. People interested in the research are advised to contact the author for the final version of the publication, or visit the DOI to the publisher's website.

- The final author version and the galley proof are versions of the publication after peer review.

- The final published version features the final layout of the paper including the volume, issue and page numbers.

Link to publication

\footnotetext{
General rights rights.

- You may freely distribute the URL identifying the publication in the public portal. please follow below link for the End User Agreement:

www.umlib.nl/taverne-license

Take down policy

If you believe that this document breaches copyright please contact us at:

repository@maastrichtuniversity.nl

providing details and we will investigate your claim.
}

Copyright and moral rights for the publications made accessible in the public portal are retained by the authors and/or other copyright owners and it is a condition of accessing publications that users recognise and abide by the legal requirements associated with these

- Users may download and print one copy of any publication from the public portal for the purpose of private study or research.

- You may not further distribute the material or use it for any profit-making activity or commercial gain

If the publication is distributed under the terms of Article $25 \mathrm{fa}$ of the Dutch Copyright Act, indicated by the "Taverne" license above, 


\section{Derivatization strategies for the detection of triamcinolone acetonide in cartilage by using matrix-assisted laser desorption/ionization mass spectrometry imaging}

Florian P.Y. Barré ${ }^{1}$, Bryn Flinders ${ }^{1}$, João P. Garcia ${ }^{2}$, Imke Jansen ${ }^{2}$, Lennart Huizing ${ }^{1}$, Tiffany Porta $^{1}$, Laura B. Creemers ${ }^{2}$, Ron M.A. Heeren ${ }^{1}$, Berta Cillero-Pastor ${ }^{1 *}$

${ }^{1}$ The Maastricht Multimodal Molecular Imaging Institute (M4I), Division of Imaging Mass Spectrometry, Maastricht University, Universiteitssingel 50, 6229 ER Maastricht, The Netherlands.

${ }^{2}$ University Medical Centre (UMC) Utrecht, Orthopedics Department, Heidelberglaan 100, 3584 CX Utrecht, The Netherlands.

Corresponding author": Dr Berta Cillero-Pastor, tel: +31 43388 1499, fax: +31 433884154 e-mail: b.cilleropastor@ maastrichtuniversity.nl 


\begin{abstract}
Osteoarthritis (OA), characterized by degeneration of the cartilaginous tissue in articular joints, severely impairs mobility in many people worldwide. The degeneration is thought to be mediated by inflammatory processes occurring in the tissue of the joint, including the cartilage. Intraarticular administered Triamcinolone acetonide (TAA) is one of the drug treatments employed to ameliorate the inflammation and pain that characterizes OA. However, the penetration and distribution of TAA into the avascular cartilage is not well understood. We employed matrixassisted laser desorption/ionization mass spectrometry imaging (MALDI-MSI), which has been previously used to directly monitor the distribution of drugs in biological tissues, to evaluate the distribution of TAA in human cartilage after in vitro incubation. Unfortunately, TAA is not easily ionized by regular electrospray ionization (ESI) or MALDI. To overcome this problem, we developed an on-tissue derivatization method with Girard's reagent T (GirT) in human incubated cartilage being able to study its distribution and quantify the drug abundance (up to $3.3 \mathrm{ng} / \mu \mathrm{l}$ ). Our results demonstrate the depth of penetration of a corticosteroid drug in human OA cartilage using MALDI-MSI.
\end{abstract}




\section{INTRODUCTION}

Osteoarthritis (OA) also known as degenerative arthritis or degenerative joint disease, results from the degeneration of cartilaginous tissue in joints and severely affects mobility. OA affects more than half of the population above 60 years of age making it the world's most common agerelated disease. ${ }^{1,2}$ The use of small molecule drugs for treatment of cartilage pathology over the past decennia has been accompanied by a lack of understanding where in the joint they distribute. Especially potent drugs with pleiotropic effects such as corticosteroids can have several side effects associated. Local accumulation is potentially pathological depending on the joint tissue. Conversely, certain levels may be needed in tissues to achieve the desired effect. Understanding the local distribution of drugs, will help fine tuning the application of intra-articular drug therapies, either by adjusting concentrations, using different physicochemical versions of the drug or administration modes, such as controlled or targeted delivery. Triamcinolone acetonide (TAA) is a synthetic corticosteroid most commonly used as a local anti-inflammatory to treat the pain and inflammation associated with OA. ${ }^{3,4} 5$ Although the effects of corticosteroids on symptoms of $\mathrm{OA}$ are ascribed to the inhibition of inflammatory mediator production, this has not been unequivocally proven. ${ }^{1}$ In fact, data on the effects of corticosteroids on cartilage have been contradictory until now and may be context- and/or dose-dependent. ${ }^{3,6,7}$

Different imaging modalities have been used to study OA; these include radiography ${ }^{8,9}$, ultrasonography ${ }^{10}$, computed tomography $(\mathrm{CT})^{11,12}$, magnetic resonance imaging (MRI) ${ }^{13}$ and positron emission tomography (PET). ${ }^{14}$ While these methods are effective for diagnosing or following patient progress, these techniques do not provide biomolecular understanding of the disease pathology. Mass spectrometry imaging (MSI) is a relatively new biomolecular tool to study OA. Compared to conventional imaging techniques, such as MRI, PET or autoradiography, MSI offers several important advantages. First, it does not require the labeling of molecules and can produce high spatial resolution images. Moreover, MSI allows for the simultaneous detection of thousands of different molecules that can be detected from histological tissues sections in a single experiment. The first publication related to OA using MSI showed that it is possible to distinguish between healthy and OA cartilage at the molecular level using secondary ion mass spectrometry (SIMS). ${ }^{15}$ It has also been shown that matrix-assisted laser desorption/ionization mass spectrometry imaging (MALDI-MSI) is able to reveal OA-specific proteins ${ }^{16}$ and identify 
peptides as markers of ageing and OA. ${ }^{17}$ The different markers in normal and OA synovium have shown the potential of this technique in furthering our understanding of the pathology. MSI is commonly applied in different drug discovery and development phases to study the efficiency, toxicity and pharmacokinetic properties of candidate molecules. ${ }^{18,19}$ MSI has been used for the detection of drugs in different organs such as kidney ${ }^{20,21}, \operatorname{liver}^{22}, \operatorname{lung}^{23,24}$ brain $^{25}$ and even in hair $^{26}$, however, this method has never been applied to study drug distributions in cartilage.

Unfortunately, TAA is difficult to detect by mass spectrometry due to the fact that the molecule is not easily protonated/deprotonated. Furthermore, it is susceptible to ion suppression by more abundant molecules such as lipids. ${ }^{27}$ In cases where compounds have poor ionization efficiency, a derivatization procedure to add a charged group directly to the molecule can increase ion yields. An additional benefit of derivatization with "soft" ionization mass spectrometry techniques such as MALDI is that the derivatization prevents isobaric overlay between the matrix and the molecules peaks by providing a shift of mass to higher $\mathrm{m} / \mathrm{z}$ values where there are fewer matrix interferences. The most common derivatization reactions of carbonyl compounds reported for analysis by "soft" ionization mass spectrometry methods are based on the formation of oximes and hydrazones. ${ }^{28,29}$ Several requirements must be considered when choosing the ideal derivatization reagent. First, the reagent should be pre-charged or include a group having high proton affinity. Second, it must contain a suitable reactive group. Finally, it should be commercially available or synthesized using inexpensive reagents groups. ${ }^{28,30}$

Here, we developed an on-tissue derivatization method using Girard's reagent T (GirT), which is a quaternary ammonium acetylhydrazine chloride that forms water-soluble hydrazones with carbonyl compounds. GirT has been previously used for the derivatization and analysis of corticosteroids by MALDI-MSI. ${ }^{31}$ In a recent study, this reagent has been used to visualize testosterone in mouse testis ${ }^{32,33}$ and corticosterone in rat adrenal and mouse brain sections. ${ }^{27} \mathrm{We}$ report that on-tissue GirT derivatization on human cartilage tissue sections enabled the detection of TAA. Accurate quantification of TAA was achieved using a deuterated TAA analogue (TAA$\mathrm{d}_{6}$ ). Furthermore, we were able to determine the distribution of TAA in human cartilage by normalizing the data against the labeled analogue. Our findings provide an optimized MALDIMSI approach to detect and quantify a corticosteroid drug (TAA) in human cartilage. 


\section{EXPERIMENTAL SECTION}

\section{Chemicals and Reagents}

2,5-dihydroxybenzoic acid (DHB), triamcinolone acetonide (TAA), Girard's reagent T (GirT), norhamane and trifluoroacetic acid (TFA) were purchased from Sigma Aldrich (Gillingham, Dorset, UK). Methanol $(\mathrm{MeOH})$ and ethanol $(\mathrm{EtOH})$ were purchased from Fisher Scientific (Loughborough, Leicestershire, UK). TAA- $\mathrm{d}_{6}$ was synthetized by Expert Synthesis Solutions (London, UK). Dulbecco's modified Eagle's medium (DMEM) and penicillin/streptomycin (P/S) were purchased from Thermo Fisher Scientific (Waltham, MA, USA). Fetal bovine serum was purchased from HyClone (Eindhoven, The Netherlands) and ammonium acetate was purchased from AMRESCO (Solon, OH, USA).

\section{Tissue Collection and Preparation}

Anonymous use of redundant tissue for research purposes is part of the standard treatment agreement with patients in the UMCU and is used in accordance with the code "appropriate use of redundant tissue for clinical research" guideline constructed by the Dutch Federation of Medical Research Societies (www.federa.org). The cartilage was obtained from three OA patients undergoing total knee arthroplasty and rinsed with PBS 1\% penicillin/streptomycin (Figure 1a,b Supporting Information). Cartilage chips (between 5x5 and 10x10mm) were placed in a 24-well plate and incubated with DMEM supplemented with $10 \%$ FBS and $1 \%$ P/S. Based on previous cartilage explant studies ${ }^{45}$, TAA was added at two different concentrations (43.5 $\mathrm{ng} / \mu 1$ and $434.5 \mathrm{ng} / \mu \mathrm{l}$ ) at a total volume of $500 \mu \mathrm{L}$ for 48 hours in a humidified incubator in an environment of $5 \% \mathrm{CO}_{2}$ and $37^{\circ} \mathrm{C}$. As a control, the tissues were incubated with drug-free culture medium (Figure 1c Supporting Information). After the incubation, cartilage chips were rinsed with ice-cold ammonium acetate buffer $(150 \mathrm{mM}, \mathrm{pH} 7.3)$, snap-frozen in liquid nitrogen, and stored at $-80^{\circ} \mathrm{C}$ until analysis (Figure 1d Supporting Information).

Snap-frozen tissues were sectioned at $-20^{\circ} \mathrm{C}$ using a Leica cryostat (Leica Microsystems, Wetzlar) and deposited on indium tin oxide (ITO) glass slides (4-8 $\Omega$ resistance, Delta Technologies, USA). 


\section{Internal Standard}

The internal standard, triamcinolone acetonide- $\mathrm{d}_{6}$ (TAA-d6, $5 \mathrm{ng} / \mu \mathrm{l}$ ) was sprayed on top of the tissue using the SunCollect sprayer (SunChrom, Friedrischsdorf, Germany) before application of the standard curve and the derivatization agent. Ten layers were applied at $40 \mu \mathrm{L} / \mathrm{min}$ (speed $\mathrm{x}$ : low 7 , speed y: medium $1, \mathrm{Z}$ position: 30 ).

\section{Standard Curve}

A dilution series of TAA was prepared in $70 \% \mathrm{MeOH}$ at the following concentrations: $0.1,0.5,1$, 2, 10, 20, 30 and $50 \mathrm{ng} / \mu \mathrm{l}$. A 10- $\mu \mathrm{l}$ aliquot of each concentration was mixed with $10 \mu \mathrm{l}$ of GirT (5 $\mathrm{mg} / \mathrm{mL}$ in $\mathrm{MeOH}$ with $0.2 \%$ TFA). The dilution series was applied on a target plate in the following sequence: $0.5 \mu \mathrm{l}$ of $\mathrm{DHB}(20 \mathrm{mg} / \mathrm{mL}$ in $70 \% \mathrm{MeOH}$ with $0.2 \% \mathrm{TFA}), 1.0 \mu \mathrm{l}$ of the TAA solution and then $0.5 \mu \mathrm{l}$ of DHB. For on-tissue experiments, $0.2 \mu \mathrm{l}$ of each concentration was manually applied on blank cartilage tissue sections before the on-tissue chemical derivatization process.

\section{On-tissue Chemical Derivatization}

On-tissue derivatization of TAA was performed with the SunCollect automated pneumatic sprayer by applying GirT ( $5 \mathrm{mg} / \mathrm{mL}$ in $\mathrm{MeOH}$ with $0.2 \%$ TFA) in a series of 18 layers. The first layer was applied at $10 \mu \mathrm{L} / \mathrm{min}$, the second layer was applied at $15 \mu \mathrm{L} / \mathrm{min}$ and all subsequent layers were sprayed at $20 \mu \mathrm{L} / \mathrm{min}$ (speed $\mathrm{x}$ : low 7, speed y: medium 1, Z position: 30). The coated tissue section was placed in a pipette tip box with $60 \mathrm{~mL}$ of $50 \% \mathrm{MeOH}$ with $0.2 \%$ TFA, in an oven set at $40^{\circ} \mathrm{C}$. After $150 \mathrm{~min}$, the sample was removed and allowed to cool down and dry in a vacuum desiccator (room temperature, $15 \mathrm{~min}$ ) before the matrix application in order to avoid subsequent hydrolysis.

\section{Matrix Application}

Fresh DHB solution (20 mg/mL in $70 \% \mathrm{MeOH}$ with $0.2 \%$ TFA) was sprayed using the SunCollect automated pneumatic sprayer in a series of 30 layers. The first layer was applied at 10 $\mu \mathrm{L} / \mathrm{min}$, the second layer was applied at $15 \mu \mathrm{L} / \mathrm{min}$ and all subsequent layers were sprayed at 20 $\mu \mathrm{L} /$ min (speed $\mathrm{x}$ : low 7 , speed $\mathrm{y}$ : medium $1, \mathrm{Z}$ position: 40 ). 


\section{MS Acquisition}

A Waters MALDI HDMS SYNAPT G2-Si mass spectrometer (Waters Corporation, Manchester, UK) equipped with a $200-\mathrm{Hz}, 355-\mathrm{nm}$ neodymium-doped yttrium aluminum garnet (Nd:YAG) laser configured to acquire MSI data and the MS/MS spectra (beam diameter of $150 \mu \mathrm{m}(\mathrm{H}) \mathrm{x}$ $100 \mu \mathrm{m}(\mathrm{W}))$. The MS/MS fragmentation was performed using an isolation window of $1 \mathrm{Da}$. MALDI-MSI data were acquired at a raster size of $100 \times 100 \mu \mathrm{m}$ in the mass range from $\mathrm{m} / z, 100$ to 1000 in positive mode. Concerning the imaging experiments, the samples were optically scanned using a flatbed scanner to produce a digital image for future reference. This image was then imported into the MALDI imaging pattern creator software (High Definition Imaging (HDI) v1.2 software, Waters) to define the region to be imaged.

A Bruker rapifleX MALDI TissuetyperTM time-of-flight (TOF) instrument from Bruker Daltonics Inc. was used for high-speed imaging at a spatial 50 × $50 \mu \mathrm{m}$ raster size. The acquisition rates were 50 pixels per second which was possible by using a 10-kHz laser and two rotating mirrors that allowed the laser beam to be moved over, and synchronized with, the rapidly moving sample. The data was acquired in the mass range $m / z 100$ to 1000 in positive ion mode.

A Bruker SolariX Fourier transform ion cyclotron resonance (FT-ICR) mass spectrometer equipped with a 9.4T superconducting magnet was used to acquire high mass resolution spectra to confirm the molecular identity of TAA. The data were acquired in the mass range 100 to 2000 $\mathrm{m} / \mathrm{z}$ in positive ion mode (100 laser shots with $2000 \mathrm{~Hz}$ frequency).

\section{Histological Staining}

After performing the MALDI-MSI experiments, the matrix was removed by submersion in EtOH for 5 minutes. The sections were stained using hematoxylin for $10 \mathrm{~min}$, Safranin $\mathrm{O} 0.1 \%$ dissolved in ultra-pure $\mathrm{H}_{2} \mathrm{O}$ for 4 min and Fast Green FCF $0.1 \%$ dissolved in ultra-pure $\mathrm{H}_{2} \mathrm{O}$ for 4 minutes. Digital images were acquired with the Mirax system (Carl Zeiss) after dehydrating steps. 


\section{Data analysis}

The profiles acquired on the target plates and the MS/MS spectra were analyzed using MassLynx v4.1 (Waters) and further processed using mMass v3.0 for presentation purposes (http://www.mmass.org/). The MALDI-MSI data acquired using the Waters MALDI HDMS SYNAPT G2-Si mass spectrometer were first converted using the HDI software v1.4 and visualized using BioMap software (Novartis, Basel, Switzerland). Regions of interest (ROIs) were manually created by BioMap for the calculation of the penetration of the drug in the tissues. For each experiment, the concentrations for dosed tissues were calculated using the standard curve obtained by the dilution series applied on blank tissues. Total ion count (TIC) was used to normalize the data until the incorporation of the labeled drug (TAA- $\mathrm{d}_{6}$ ) which was used to perform quantitation. The results of the experiments were averaged to obtain the final concentrations of incubated tissues. The standard deviation and the relative standard deviation were calculated for both 434.5 and $43.5 \mathrm{ng} / \mu \mathrm{l}$ TAA doses. ${ }^{34}$ FlexImaging v5.0 was used to process the mass spectral data acquired using the Bruker rapifleX. DataAnalysis 4.4 was used to analyze the FT data. The co-registration of the optical images, stained images and MSI data was done using markers on the ITO slides in the FlexImaging software.

\section{RESULTS AND DISCUSSION}

Detection of TAA. To gain insight about TAA in OA, we aimed to derivatize, localize, and quantify drug levels within dosed human cartilage by MALDI-MSI. We first studied the behavior of the drug with different matrices by applying a TAA standard on a target plate. The detection of the standard was tested in both positive and negative ion modes with two different matrices, DHB and norharmane.

The peak at $m / z 435.23[\mathrm{M}+\mathrm{H}]^{+}$was observed with low intensity, as well as the sodium adduct $m / z 457.22[\mathrm{M}+\mathrm{Na}]^{+}$and potassium adduct at $m / z 473.19[\mathrm{M}+\mathrm{K}]^{+}$in positive ion mode for DHB (shown in Figure 1a). However, in negative ion mode, we did not obtain any signal using norharmane as a matrix (data not shown). Because of its hydrophobic properties, TAA required a chemical derivatization process in order to improve its ionization efficiency (Figure 1b). Two hydrazine-based reagents were chosen as candidates to derivatize TAA: the efficacy of the 
reaction of 2,4-Dinitrophenylhydrazine (DNPH) and Girard's reagent T (GirT) were compared under the same conditions (2 hours at ambient temperature, $100 \mathrm{ng} / \mu 1 \mathrm{TAA}$; DHB). DNPH is the most commonly used reagent to improve the detection of carbonyl-containing compounds. ${ }^{29}$ Our experiments demonstrated higher ion intensities with GirT (3.93 $10^{7}$ a.u. for TAA at $m / z$ 548.31 $\left.[\mathrm{M}]^{+}\right)$as well as the radical cation of TAA at $\mathrm{m} / \mathrm{z} 434.24\left([\mathrm{M}]^{+\cdot}\right)$ compared to DNPH $\left(7.3410^{3}\right.$ a.u. at $m / z 615.23[\mathrm{M}+\mathrm{H}]^{+}$) (Figure 2, Supporting Information).

Method development and optimization of the standard curve. With the successful detection of TAA using GirT, we proceeded to optimize the derivatization method. A TAA dilution series was prepared $(0.1,0.5,1,2,10,20,30$ and $50 \mathrm{ng} / \mu \mathrm{l})$ and spotted on a target plate. A correlation coefficient $\left(\mathrm{R}^{2}\right)$ of 0.9522 was obtained (triplicate's average) with a relative intensity up to 4.62 $10^{-2}$ a.u. for the highest concentration (Figure $2 \mathrm{a}$ ). When the reaction time was increased to 2.5 hours, we obtained a $\mathrm{R}^{2}$ of 0.9823 (triplicate's average) and a higher relative intensity for 50 ng/ $\mu \mathrm{l}$ up to $1.3210^{-1}$ a.u. (Figure $2 \mathrm{~b}$ ). Other studies have shown that the reaction can be carried out at high temperatures for a shorter time. ${ }^{35}$ The mixed solution of TAA and GirT was incubated in an oven $\left(40^{\circ} \mathrm{C}\right)$ for 1 hour which resulted in an $\mathrm{R}^{2}$ of 0.9112 (triplicate's average) and a relative intensity of $5.7110^{-1}$ a.u. (Figure $2 \mathrm{c}$ ). We continued with the $40{ }^{\circ} \mathrm{C}$ incubation but increased the time to 2.5 hours; both the linearity of the conversion of TAA to hydrazones $\left(\mathrm{R}^{2}=\right.$ 0.998, triplicate's average) and the relative intensity of TAA (8.91 10 $10^{-1}$ a.u.) increased. From these data, we determined that incubation at $40^{\circ} \mathrm{C}$ for 2.5 hours yielded the most optimal conditions for TAA derivatization with GirT. Girard's reagent T reacts with the carbonyl functionality of aldehydes and ketones to form a hydrazone derivative, which incorporates a permanent positive charge. Reactions using Girard's reagents are typically conducted in organic solvents in the presence of an acidic catalyst and high temperatures. ${ }^{33,35,36}$ The experiments were initially performed at room temperature for 2 hours, this resulted in a instability and low yield of the derivative, as shown in the standard curve. As a result the temperature was increased to $40^{\circ} \mathrm{C}$, this improved the yield of the derivative (10 fold) in a much shorter time. The yield of the derivative was further improved by increasing the reaction time to 2.5 hours at $40^{\circ} \mathrm{C}$, no further increase in the yield of the derivative was observed with longer reaction times possibly due to the reaction being complete. The temperature was not further increased in order to maintain the integrity of the tissue sections. 
On-tissue chemical derivatization. Next, we evaluated the efficiency of our derivatization protocol on tissue sections, using rat liver tissue. Previous studies have shown that when a dilution series is applied on tissue a linear standard curve can be obtained. ${ }^{37-39}$ The standard curve was spotted on a liver tissue section and the number of GirT and matrix layers were tested. While optimizing the efficiency of TAA derivatization on tissue, we observed spatial delocalization due to GirT not drying on the slide. This can be explained by the chemical properties of GirT: it is a quaternary amine salt and very hydroscopic. To solve this problem, we employed a soft/dry matrix application protocol, increasing the number of passes but decreasing the flow rate of the SunCollect (30 layers, $20 \mu \mathrm{l} / \mathrm{min}$ ) to let the matrix dry between two passes (data not shown).

In order to verify the derivatization of the drug on the cartilage tissue sections, 4 blank tissues, 3 tissues incubated in the presence of $434.5 \mathrm{ng} / \mu \mathrm{l}$ TAA and 3 tissues with $43.5 \mathrm{ng} / \mu \mathrm{l}$ TAA were mounted on the same ITO slide per every donor. It is important to note that for this derivatization protocol, it is not possible to use tissues embedded in gelatin since the reaction of derivatization involves a step in the oven at $40^{\circ} \mathrm{C}$. We showed with this experiment the potential to perform quantitation; the average signal for dosed tissues in $434.5 \mathrm{ng} / \mu \mathrm{l}$ was higher than incubated tissues in $43.5 \mathrm{ng} / \mu \mathrm{l}$ (data not shown). Using the rapifleX, we were able to detect a very low signal for non-derivatized TAA at $\mathrm{m} / z$ 435.2 $[\mathrm{M}+\mathrm{H}]^{+}$. The TAA signal increased 78-fold between $\mathrm{m} / z 435.2$ $[\mathrm{M}+\mathrm{H}]^{+}$and $m / z, 548.3[\mathrm{M}]^{+}$thanks to the derivatization protocol. The data and images for these experiments were normalized with TIC. MS/MS was performed on the peak at $\mathrm{m} / \mathrm{z} 548.31$ and confirmed the presence of TAA (Figure 3, Supporting Information). FT-ICR data were acquired to confirm the identity with an accuracy of $0.55 \mathrm{ppm}$ (Figure 4, Supporting Information). From these data, we conclude that derivatization using GirT increased the TAA signal in tissue sufficiently for quantitation.

\section{Optimization of the quantitation method using deuterated TAA on blank cartilage tissue} sections. It has been shown that an internal standard is needed in order to quantify the levels of an endogenous compound. ${ }^{34}$ An internal standard also improves scan-to-scan reproducibility and improves the linearity of the calibration curve. ${ }^{40}$ Quantitation strategies using an internal standard have been successfully applied to quantify drug levels in tissue. ${ }^{25}$ Deuterated analogues routinely perform best as internal standards due to their similar chemical characteristics to the drug under study. Therefore, we employed a deuterated analogue of TAA to perform quantitative analyses 
(Figure 3a, b). The behavior and ionization efficiency of both TAA and TAA- $\mathrm{d}_{6}$ were assessed. First, a dilution series was prepared for TAA and TAA-d $6(0.1,0.5,1,2,10,20,30$ and $50 \mathrm{ng} / \mu \mathrm{l})$. The standard curves for TAA and TAA- $\mathrm{d}_{6}$ were spotted on a target plate. The $\mathrm{R}^{2}$ values were similar for TAA and TAA-d 6 (0.9928 and 0.9909, respectively, in an average of three experiments), and the calibration curves were comparable (Figure 3c), indicating an identical ionization efficiency of the drug and its deuterated analogue. An 8-point standard curve was prepared on untreated cartilage tissue sections on the same ITO slide by manually applying an aliquot of $0.2 \mu \mathrm{l}$. We respectively obtained $\mathrm{R}^{2}$ values of 0.9903 and 0.9920 for TAA and TAA-d 6 (average of three experiments) with two fitted linear calibration curves. Moreover, the relative intensities were similar for each measured point of the curve (Figure 3d). We conclude that TAA and TAA- $\mathrm{d}_{6}$ have the same ionization efficiency, the same response factor and the same behavior in terms of ion-suppression effects, which makes TAA- $\mathrm{d}_{6}$ an ideal choice for quantitation of TAA.

Quantitation of cartilage incubated with TAA. To quantify TAA in human cartilage after incubation with the drug, untreated cartilage sections, tissues from three human cartilage donors incubated in a solution at $434.5 \mathrm{ng} / \mu \mathrm{l}$ of TAA and three with $43.5 \mathrm{ng} / \mu \mathrm{l}$ of TAA were mounted on the same ITO slide. The internal standard was applied directly onto the tissue to use it as calibration curve. ${ }^{41}$ Nilsson et al. spotted the standard on top of the control tissue sections in order to confirm the identification of the drug crystals in kidney, by using this method. ${ }^{42}$ Applying the internal standard on top of the tissue allows a uniform repartition of the standard all over the dosed sample. The ability to reliably and reproducibly deposit standards homogeneously on tissue is achieved with automatic deposition devices. Here, the internal standard (TAA-d 6 ) was sprayed on top of the tissue using the SunCollect. ${ }^{41,43}$ An 8-point dilution series was spotted on the blank tissue sections in order to obtain a calibration curve. The experiment was repeated three times per donor using consecutive sections, resulting in standard curves with $\mathrm{R} 1^{2}=0.9918, \mathrm{R} 2^{2}=$ 0.9993 and $\mathrm{R}^{2}=0.9907$. On cartilage, the TAA average intensity $\left(\mathrm{m} / z, 548.31[\mathrm{M}]^{+}\right)$was normalized with the internal standard (Figure 4a). Using the calibration curves, we calculated the TAA concentration in the dosed tissues (Figure 4b): TAA in higher-dosed tissues was $22.19 \pm$ $2.11 \mathrm{ng} / \mu \mathrm{l}$ and in lower-dosed tissues was $3.66 \pm 0.37 \mathrm{ng} / \mu \mathrm{l}$ (average \pm SD from 3 experiments; Figure 4c). The concentrations were expressed in $\mathrm{ng} / \mu \mathrm{l}$ following previous studies. ${ }^{43}$ The 
experiment was repeated with cartilage from two other OA patients. The concentrations for the second patient were $10.34 \pm 1.01 \mathrm{ng} / \mu \mathrm{l}$ for the highest-dosed tissues and $6.44 \pm 0.57 \mathrm{ng} / \mu \mathrm{l}$ in lowest dosed tissues (average \pm SD from 3 experiments) obtaining standard curves with $\mathrm{R}^{2}$ above 0.99 (0.997, 0.9917 and 0.9976, respectively). The values for the third patient cartilage chips were $6.80 \pm 0.05 \mathrm{ng} / \mu \mathrm{l}$ and $4.74 \pm 0.23 \mathrm{ng} / \mu \mathrm{l}$ for the highest and lowest dosed tissues, respectively (Figure 4d). Moreover, TAA was also detectable in tissues incubated at $4.35 \mathrm{ng} / \mu \mathrm{l}$ (data not shown). The deuterated drug analogue reduced intra- tissue irregularities and allowed the drug quantitation. The precision of these experiments was $6.8 \mathrm{mDa}$.

Distribution of triamcinolone acetonide within the cartilage. The distribution of the drug was investigated at a spatial resolution of $50 \mu \mathrm{m}$. Different methods of normalization have been applied: Median, TIC and labeled normalization. Staining of the tissue was performed after data acquisition to correlate the different images with the different cartilage zones (Figure 5a,b). Our findings show differences in the localization of TAA depending on the normalization method that has been used due to the difference in dynamic range between these methods. ${ }^{44}$ The nonnormalized image did not display a particular distribution of the drug within the tissue (Figure 5c). Median normalization and TIC showed a non-homogeneous distribution of TAA within the tissue (Figure 5d, e) and a higher intensity in the superficial area of the cartilage. In comparison, normalization against the labeled analogue displayed a different distribution of the drug. With this normalization approach, the drug is concentrated in the middle zone of the incubated tissue (Figure 5f). The internal standard is homogeneously distributed on top of the tissue, however its ionization efficiency depends on the structure of the cartilage which leads to different absolute intensities observed between the different layers of the sections: the superficial layer of the cartilage contains a relatively high number of chondrocytes, being responsible of the protection and maintenance of deeper layers. This zone is in contact with synovial fluid and is able to resist the shear and tensile forces imposed by articulation. This layer is damaged and thinner in OA joints. ${ }^{45}$ Immediately underneath the superficial zone is the middle zone, representing about $60 \%$ of the total cartilage volume, and it contains proteoglycans and thicker collagen fibrils. In this layer, the collagen is organized obliquely, and the chondrocytes are spherical and at low density. The deep zone contains the largest diameter collagen fibrils, the highest proteoglycan content, and the lowest water concentration. ${ }^{46}$ The differences in cell number, proteoglycan and water 
content could affect the ionization efficiency of TAA, as well as, the metabolism of the compound. Because of the role of each zone, it is extremely important to understand the diffusion of TAA and other drugs that are commonly used for OA treatment into the cartilage. We confirmed the importance of using an internal standard to perform quantitation but also to correct for tissue heterogeneity. ${ }^{44}$ In addition, the use of a labeled standard is crucial because TIC normalization is not able to take in account the structure of the tissue and by consequence the ion suppression effect. Normalization against a deuterated internal standard makes possible drug quantitation, which correlates with liquid chromatography-tandem mass spectrometry (LC-MS). ${ }^{47}$ LC-MS is a very robust tool to perform identification and quantitation of drugs. ${ }^{48,49}$ The drawback of this technique is the loss of spatial information as an extraction of the tissue has to be performed before analysis. With MSI, the spatial distribution of the drug is preserved. The local ionization efficiency in imaging MS is tissue-type dependent. The use of the internal standard allows the correction of these tissue-dependent ionization differences as the deuterated analogue behaves the same as the drug in terms of extraction, co-crystallization with the matrix, and ionization efficiency. ${ }^{25}$ In addition, Pirman et $a l$. showed that the use of an internal standard improves the quality of the MS images ${ }^{40}$ and moreover, the deuterated analogue is demonstrated to improve the quantitation. ${ }^{50,51}$ In a recent study, Chumblay et al. compared different ways of applying the internal standard, showing that spraying the internal standard on tissue was the most accurate technique compared with HPLC-MS, obtaining similar concentrations with both aproaches. ${ }^{52}$ Therefore LC-MS and MALDI-MSI are two complementary tools in drug discovery to look at the quantitation and the distribution/penetration of the drug within biological tissues. Other strategies such as liquid extraction surface analysis (LESA) can provide an intermediate solution since it provides information regarding the spatial distribution; it can be coupled to LC, and therefore improving the sensitivity, limiting tissue suppression effect and eliminating matrix interferences. However, typically the spatial resolution is limited to hundreds of micrometers. ${ }^{53,54}$ To our knowledge, there are no previous studies that demonstrate if TAA is actually penetrating the cartilage. Only measurements on synovial fluid or plasma are used as read outs. 55,56

The low TAA amounts we measured in cartilage explants incubated in two different concentrations, can be due to the fact that the drug may be metabolized at $\sim 48 \mathrm{~h}$, so we were only able to measure the remaining intact portion. Additionally, we observed a patient dependent 
difference in the speed of of TAA metabolisms. This could be due to differences in OA grade, cellularity or the composition of the extracellular matrix. Whether TAA concentrations will be higher with shorter incubation times $(<48 \mathrm{~h})$ in other areas of the cartilage remains to be determined. Whereas our study is based on incubated tissues, this method is applicable to treated tissue to evaluate drug distribution and to correlate the effects of the drug with its quantified distribution.

In summary, the detection and quantification of the anti-inflammatory TAA compound at $50 \mu \mathrm{m}$ of lateral resolution for incubated tissues opens the door to understand the behavior of these pharmaceuticals in the treatment of OA and other inflammatory pathologies. Our work provides an important step for further studies examining the distribution of TAA in OA cartilage.

\section{CONCLUSIONS}

These studies report that drug derivatization combined with MALDI-MSI is an innovative way to study the penetrance of triamcinolone acetonide within treated human cartilage. To the best of our knowledge, this is the first paper to report the detection and quantification of a drug in cartilage tissues by MSI. Future experiments must study the distribution of the drug at shorter and longer times of incubation as well as its distribution in an in vivo model by using the method presented in this paper. We demonstrated and confirmed the applicability of an isotopically labelled internal standard to perform an accurate and quantitative study of drug distribution within biological tissues. 


\section{REFERENCES}

(1) Martel-Pelletier, J. Osteoarthritis and cartilage / OARS, Osteoarthritis Research Society 2004, 12 Suppl A, S31-33.

(2) Fautrel, B.; Bourgeois, P. Drugs 2000, 59, 1-9.

(3) Schwartz, S. New York state journal of medicine 1960, 60, 3422-3425.

(4) Ostergaard, M.; Halberg, P. Biodrugs 1998, 9, 95-103.

(5) Bodick, N.; Lufkin, J.; Willwerth, C.; Hauben, J.; Kumar, A.; Boen, P.; Bolognese, J.; Schoonmaker, C.; Clayman, M. Osteoarthr Cartilage 2015, 23, A360-A361.

(6) Fautrel, B.; Bourgeois, P. Drugs 2000, 59 Spec No 1, 1-9.

(7) Ostergaard, M.; Halberg, P. BioDrugs : clinical immunotherapeutics, biopharmaceuticals and gene therapy 1998, 9, 95-103.

(8) Isik, D.; Isik, C.; Apaydin, N.; Ustu, Y.; Ugurlu, M.; Bozkurt, M. Clin Anat 2015, 28, 672-677.

(9) Hirvasniemi, J.; Thevenot, J.; Immonen, V.; Liikavainio, T.; Pulkkinen, P.; Jamsa, T.; Arokoski, J.; Saarakkala, S. Osteoarthr Cartilage 2014, 22, S268-S269.

(10) Riecke, B. F.; Christensen, R.; Torp-Pedersen, S.; Boesen, M.; Gudbergsen, H.; Bliddal, H. Osteoarthr Cartilage 2014, 22, 1675-1691.

(11) Honkanen, J. T. J.; Danso, E. K.; Suomalainen, J. S.; Tiitu, V.; Korhonen, R. K.; Jurvelin, J. S.; Toyras, J. Osteoarthr Cartilage 2015, 23, 1367-1376.

(12) Kokkonen, H. T.; Suomalainen, J. S.; Joukainen, A.; Kroger, H.; Sirola, J.; Jurvelin, J. S.; Salo, J.; Toyras, J. J Orthop Res 2014, 32, 403-412.

(13) Schoenbauer, E.; Szomolanyi, P.; Shiomi, T.; Juras, V.; Zbyn, S.; Zak, L.; Weber, M.; Trattnig, S. J Biomech 2015, 48, 3349-3355.

(14) Hirata, Y.; Inaba, Y.; Kobayashi, N.; Ike, H.; Yukizawa, Y.; Fujimaki, H.; Tezuka, T.; Tateishi, U.; Inoue, T.; Saito, T. J Orthop Res 2015, 33, 78-83.

(15) Cillero-Pastor, B.; Eijkel, G.; Kiss, A.; Blanco, F. J.; Heeren, R. M. A. Anal Chem 2012, 84, 8909-8916.

(16) Cillero-Pastor, B.; Eijkel, G. B.; Blanco, F. J.; Heeren, R. M. A. Anal Bioanal Chem 2015, 407, 22132222.

(17) Peffers, M. J.; Cillero-Pastor, B.; Eijkel, G. B.; Clegg, P. D.; Heeren, R. M. A. Arthritis Res Ther 2014, 16.

(18) Prideaux, B.; Stoeckli, M. Journal of proteomics 2012, 75, 4999-5013.

(19) Greer, T.; Sturm, R.; Li, L. Journal of proteomics 2011, 74, 2617-2631.

(20) Bruinen, A. L.; van Oevelen, C.; Eijkel, G. B.; Van Heerden, M.; Cuyckens, F.; Heeren, R. M. Journal of the American Society for Mass Spectrometry 2016, 27, 117-123.

(21) Lalowski, M.; Magni, F.; Mainini, V.; Monogioudi, E.; Gotsopoulos, A.; Soliymani, R.; Chinello, C.; Baumann, M. Nephrology, dialysis, transplantation : official publication of the European Dialysis and Transplant Association - European Renal Association 2013, 28, 1648-1656.

(22) Barry, J. A.; Groseclose, M. R.; Robichaud, G.; Castellino, S.; Muddiman, D. C. Int J Mass Spectrom 2015, 377, 448-155.

(23) Marko-Varga, G.; Fehniger, T. E.; Rezeli, M.; Dome, B.; Laurell, T.; Vegvari, A. Journal of proteomics 2011, 74, 982-992.

(24) Zecchi, R.; Trevisani, M.; Pittelli, M.; Pedretti, P.; Manni, M. E.; Pieraccini, G.; Pioselli, B.; Amadei, F.; Moneti, G.; Catinella, S. European journal of mass spectrometry 2013, 19, 475-482.

(25) Pirman, D. A.; Reich, R. F.; Kiss, A.; Heeren, R. M.; Yost, R. A. Anal Chem 2013, 85, 1081-1089.

(26) Flinders, B.; Cuypers, E.; Zeijlemaker, H.; Tytgat, J.; Heeren, R. M. Drug testing and analysis 2015, 7, 859-865.

(27) Cobice, D. F.; Mackay, C. L.; Goodwin, R. J.; McBride, A.; Langridge-Smith, P. R.; Webster, S. P.; Walker, B. R.; Andrew, R. Analytical chemistry 2013, 85, 11576-11584.

(28) Zaikin, V. G.; Halket, J. M. European journal of mass spectrometry 2006, 12, 79-115. 
(29) Flinders, B.; Morrell, J.; Marshall, P. S.; Ranshaw, L. E.; Clench, M. R. Anal Bioanal Chem 2015, 407, 2085-2094.

(30) Cartwright, A. J.; Jones, P.; Wolff, J. C.; Evans, E. H. Rapid communications in mass spectrometry : RCM 2005, 19, 1058-1062.

(31) Mitchel, R. E.; Birnboim, H. C. Analytical biochemistry 1977, 81, 47-56.

(32) Shimma, S.; Kumada, H. O.; Taniguchi, H.; Konno, A.; Yao, I.; Furuta, K.; Matsuda, T.; Ito, S. Anal Bioanal Chem 2016.

(33) Cobice, D. F.; Livingstone, D. E.; Mackay, C. L.; Goodwin, R. J.; Smith, L. B.; Walker, B. R.; Andrew, R. Analytical chemistry 2016.

(34) Takai, N.; Tanaka, Y.; Saji, H. Mass spectrometry 2014, 3, A0025.

(35) Griffiths, W. J.; Liu, S.; Alvelius, G.; Sjovall, J. Rapid communications in mass spectrometry : RCM 2003, 17, 924-935.

(36) Naven, T. J.; Harvey, D. J. Rapid communications in mass spectrometry : RCM 1996, 10, 1361-1366.

(37) Nilsson, A.; Fehniger, T. E.; Gustavsson, L.; Andersson, M.; Kenne, K.; Marko-Varga, G.; Andren, P. E. Plos One 2010, 5, e11411.

(38) Chen, J.; Hsieh, Y.; Knemeyer, I.; Crossman, L.; Korfmacher, W. A. Drug metabolism letters 2008, 2, 14.

(39) Reyzer, M. L.; Hsieh, Y.; Ng, K.; Korfmacher, W. A.; Caprioli, R. M. J Mass Spectrom 2003, 38, 10811092.

(40) Pirman, D. A.; Yost, R. A. Anal Chem 2011, 83, 8575-8581.

(41) Goodwin, R. J.; Mackay, C. L.; Nilsson, A.; Harrison, D. J.; Farde, L.; Andren, P. E.; Iverson, S. L. Anal Chem 2011, 83, 9694-9701.

(42) Nilsson, A.; Forngren, B.; Bjurstrom, S.; Goodwin, R. J.; Basmaci, E.; Gustafsson, I.; Annas, A.; Hellgren, D.; Svanhagen, A.; Andren, P. E.; Lindberg, J. Plos One 2012, 7, e47353.

(43) Fehniger, T. E.; Vegvari, A.; Rezeli, M.; Prikk, K.; Ross, P.; Dahlback, M.; Edula, G.; Sepper, R.; MarkoVarga, G. Anal Chem 2011, 83, 8329-8336.

(44) Kallback, P.; Shariatgorji, M.; Nilsson, A.; Andren, P. E. Journal of proteomics 2012, 75, 4941-4951.

(45) Pritzker, K. P.; Gay, S.; Jimenez, S. A.; Ostergaard, K.; Pelletier, J. P.; Revell, P. A.; Salter, D.; van den Berg, W. B. Osteoarthritis and cartilage / OARS, Osteoarthritis Research Society 2006, 14, 13-29.

(46) Sophia Fox, A. J.; Bedi, A.; Rodeo, S. A. Sports health 2009, 1, 461-468.

(47) Schulz, S.; Gerhardt, D.; Meyer, B.; Seegel, M.; Schubach, B.; Hopf, C.; Matheis, K. Anal Bioanal Chem 2013, 405, 9467-9476.

(48) Cao, Z.; Kaleta, E.; Wang, P. Journal of analytical toxicology 2015, 39, 335-346.

(49) Blackburn, M. Bioanalysis 2013, 5, 2933-2946.

(50) Reich, R. F.; Cudzilo, K.; Levisky, J. A.; Yost, R. A. Journal of the American Society for Mass Spectrometry 2010, 21, 564-571.

(51) Clemis, E. J.; Smith, D. S.; Camenzind, A. G.; Danell, R. M.; Parker, C. E.; Borchers, C. H. Anal Chem 2012, 84, 3514-3522.

(52) Chumbley, C. W.; Reyzer, M. L.; Allen, J. L.; Marriner, G. A.; Via, L. E.; Barry, C. E., 3rd; Caprioli, R. M. Anal Chem 2016, 88, 2392-2398.

(53) Eikel, D.; Vavrek, M.; Smith, S.; Bason, C.; Yeh, S.; Korfmacher, W. A.; Henion, J. D. Rapid communications in mass spectrometry : RCM 2011, 25, 3587-3596.

(54) Swales, J. G.; Tucker, J. W.; Spreadborough, M. J.; Iverson, S. L.; Clench, M. R.; Webborn, P. J.; Goodwin, R. J. Analytical chemistry 2015, 87, 10146-10152.

(55) Chen, C. L.; Sailor, J. A.; Collier, J.; Wiegand, J. Journal of veterinary pharmacology and therapeutics 1992, 15, 240-246.

(56) Hooten, W. M.; Nicholson, W. T.; Gazelka, H. M.; Reid, J. M.; Moeschler, S. M.; Lamer, T. J. Regional anesthesia and pain medicine 2016, 41, 75-79. 


\section{ACKNOWLEDGEMENTS}

The work was performed in the M4I research program that was financially supported by the Dutch Province of Limburg as part of the "LINK" program. F. P. Y. Barré and J. P. Garcia received funding from the European Union's Horizon 2020 research and innovation program under the Marie Sklodowska-Curie Program, TargetCare (ITN-2014-ETN 642414). I. Jansen, L. B. Creemers and B. Cillero-Pastor have been also supported by ZonMw (435002008), Life Sciences Health.

\section{CONFLICT OF INTEREST DISCLOSURE}

The authors declare no competing financial interest 


\section{FIGURES}

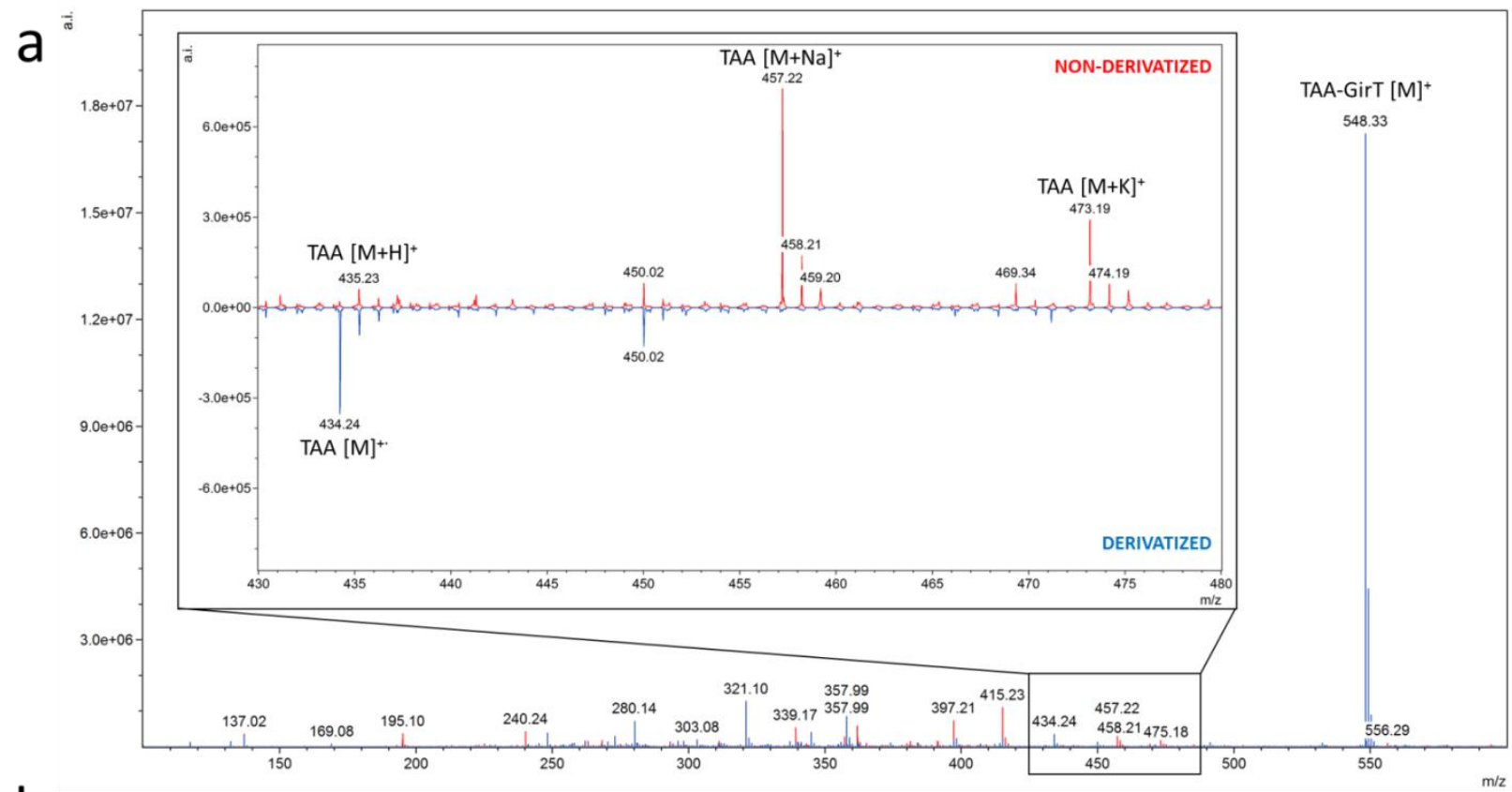

b

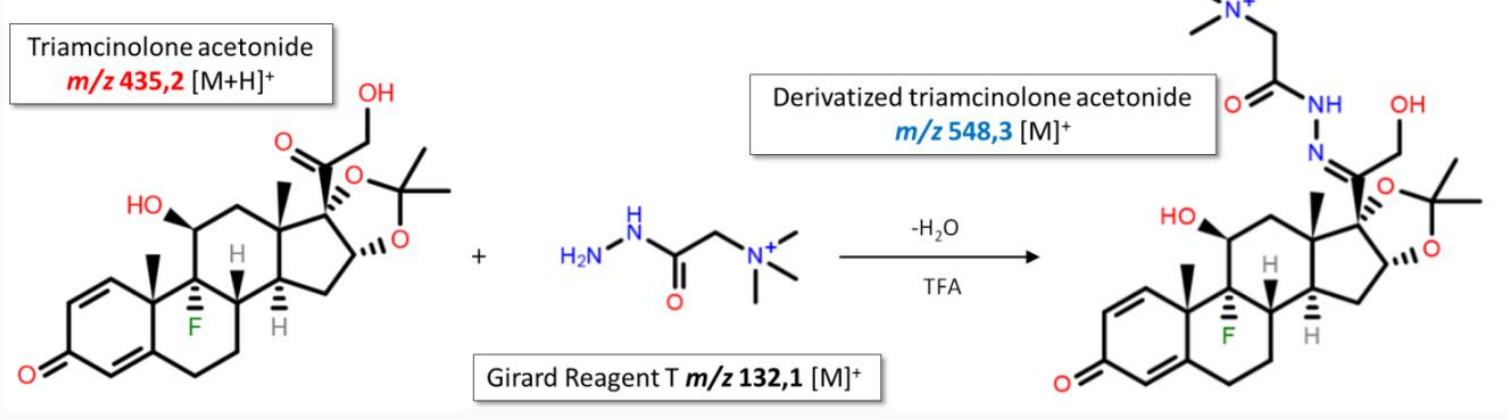

Figure 1. Derivatization of triamcinolone acetonide (TAA) with Girard reagent T (GirT) on a target plate. (a) Non-derivatized TAA was detectable at $\mathrm{m} / \mathrm{z} 435.23[\mathrm{M}+\mathrm{H}]^{+}$as well as cation species at $m / z, 457.22[\mathrm{M}+\mathrm{Na}]^{+}$and $\mathrm{m} / z, 473.19[\mathrm{M}+\mathrm{K}]^{+}$. Using the derivatization protocol, nonderivatized-TAA was detectable at $\mathrm{m} / z$ 434.24 [M] ${ }^{+\cdot}$ but the highest signal was for the derivatized-TAA at $m / z 548.33\left[\mathrm{M}^{+}\right.$. (b) TAA was mixed with GirT obtaining the derivatized form of TAA. 

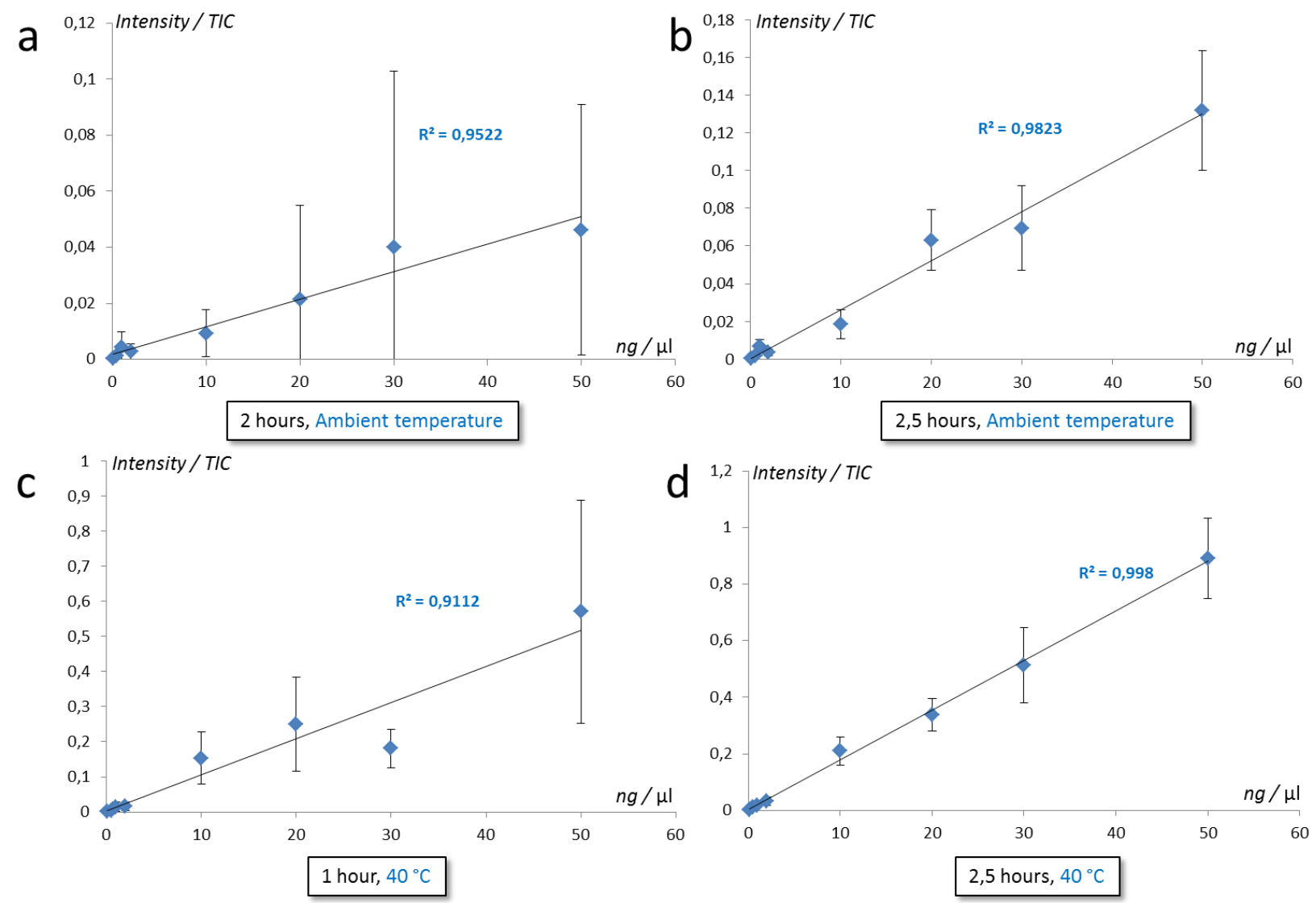

Figure 2. Optimization of the derivatization reaction using a 8 point calibration curve. The optimization of the chemical reaction has been performed by mixing TAA with GirT for (a) 2 hours and (b) 2.5 hours at ambient temperature. (c) The derivatization process shows a higher intensity $\left(5.7110^{-1}\right)$ placing the solution in an oven for 1 hour. Optimal and reproducible conditions were (d) 2.5 hours at $40^{\circ} \mathrm{C}$. Each experiment has been repeated 3 times and the averaged $\mathrm{R}^{2}$ is represented in this figure. 

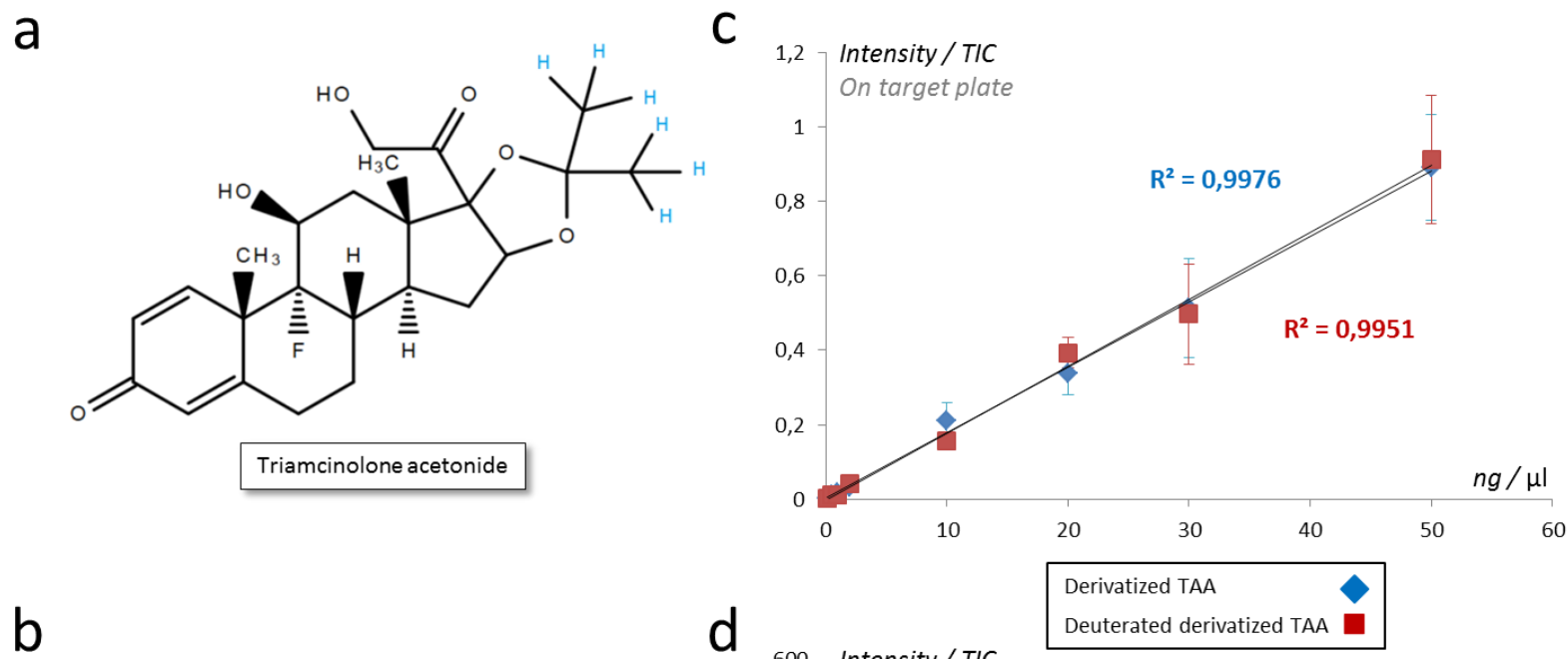

b
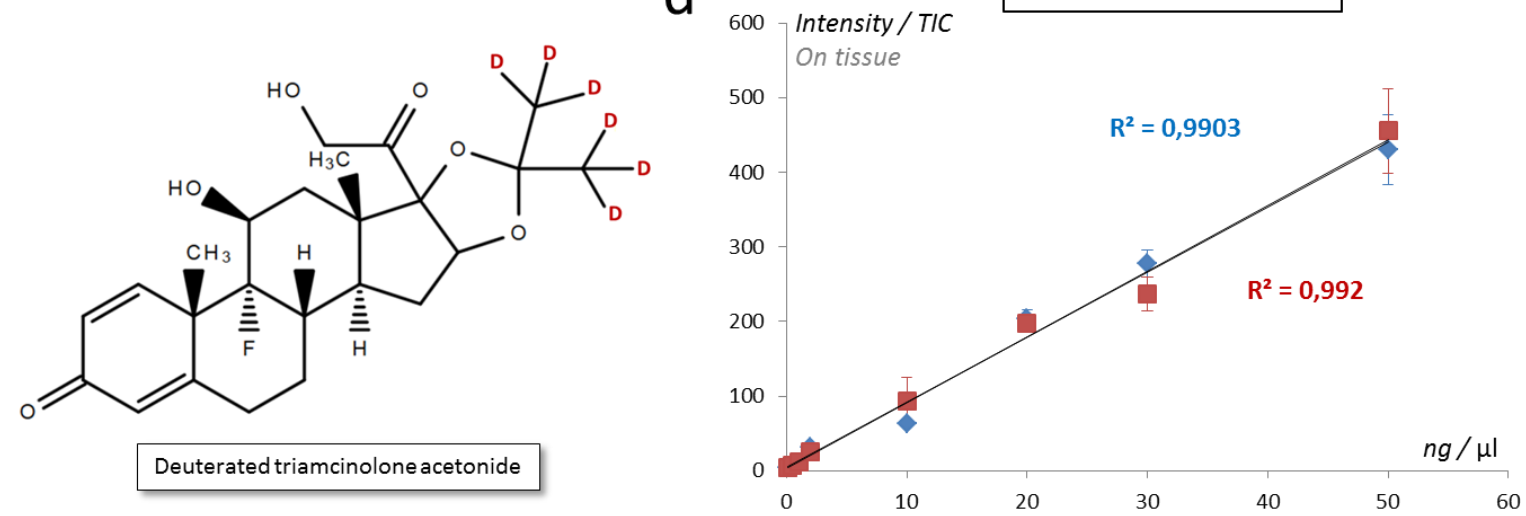

Figure 3. Behavior of the triamcinolone acetonide and deuterated triamcinolone acetonide on a target plate and on tissue. Chemical structures of (a) TAA and (b) deuterated analogue TAA- $\mathrm{d}_{6}$, hydrogen atoms have been replaced with deuterium atoms inducing a mass shift of +6 $\mathrm{m} / \mathrm{z}$ on the mass spectrum. (c) Standard curves of TAA $\left(\mathrm{m} / \mathrm{z} 548.3[\mathrm{M}]^{+}\right)$and TAA-d $6(\mathrm{~m} / \mathrm{z} 554.3$ $[\mathrm{M}]^{+}$) spotted on a target plate. (d) Standard curves of TAA and TAA-d 6 spotted on blank cartilage tissue sections. The standard curves have been spotted on the same target plate and on the same ITO slide in triplicate. 

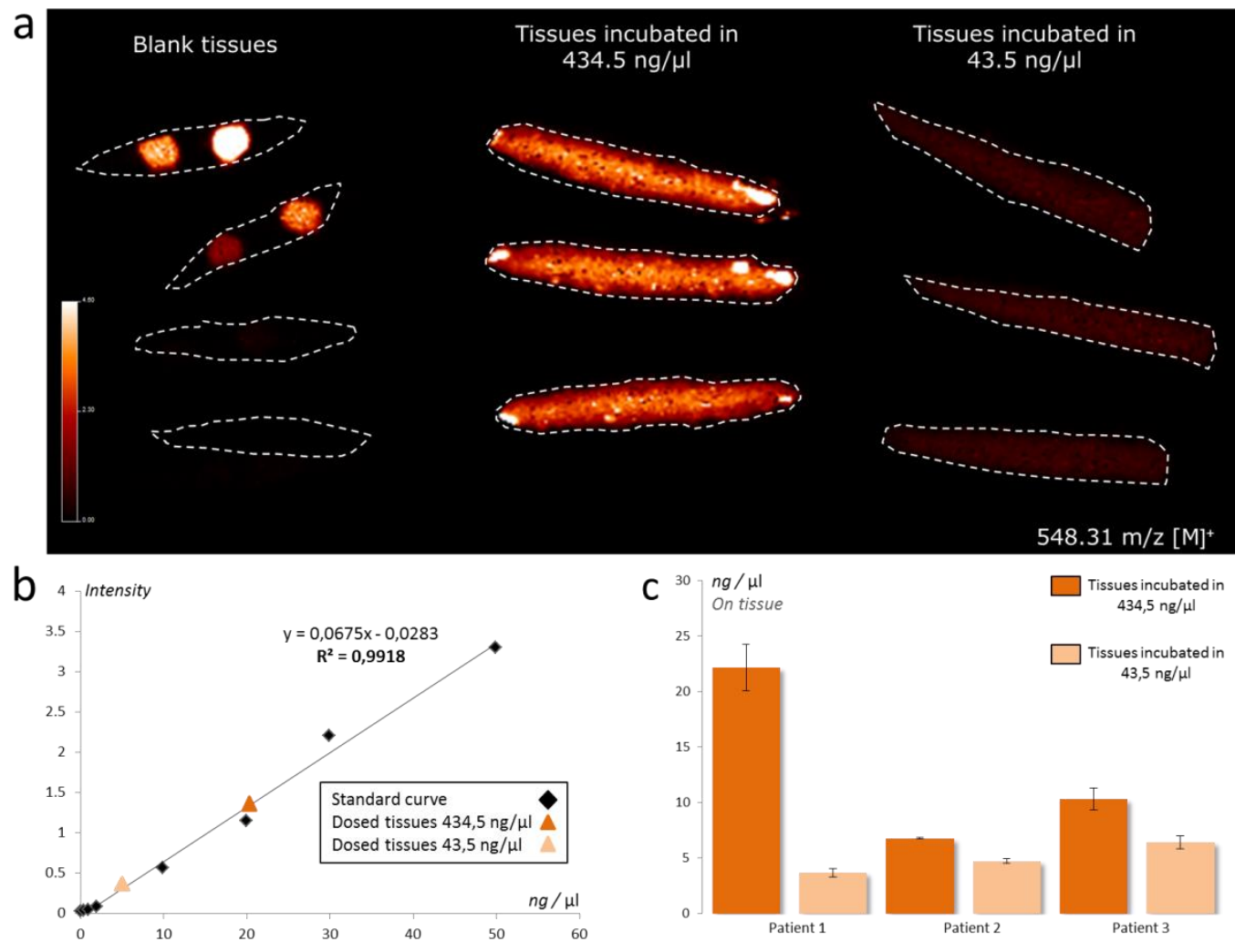

\begin{tabular}{|c|c|c|c|c|c|c|}
\hline \multirow[b]{2}{*}{ Concentration Incubated tissues } & \multicolumn{2}{|c|}{ Patient 1} & \multicolumn{2}{|c|}{ Patient 2} & \multicolumn{2}{|c|}{ Patient 3} \\
\hline & $434,5 \mathrm{ng} / \mu \mathrm{l}$ & $43,5 \mathrm{ng} / \mu \mathrm{l}$ & $434,5 \mathrm{ng} / \mu \mathrm{l}$ & $43,5 \mathrm{ng} / \mu \mathrm{l}$ & $434,5 \mathrm{ng} / \mu \mathrm{l}$ & $43,5 \mathrm{ng} / \mu \mathrm{l}$ \\
\hline Average concentration Experiment $1(\mathrm{ng} / \mu \mathrm{l})$ & 20.56 & 4.04 & 6.79 & 4.59 & 9.44 & 5.96 \\
\hline Average concentration Experiment $2(\mathrm{ng} / \mu \mathrm{l})$ & 21.42 & 3.65 & 6.75 & 5.00 & 10.16 & 6.29 \\
\hline Average concentration Experiment $3(\mathrm{ng} / \mu \mathrm{l})$ & 24.57 & 3.30 & 6.86 & 4.62 & 11.43 & 7.08 \\
\hline Global Average & 22.185 & 3.661 & 6.800 & 4.738 & 10.344 & 6.443 \\
\hline Standard Deviation & 2.112438 & 0.365774 & 0.05553 & 0.231369 & 1.005572 & 0.572187 \\
\hline Relative Standard Deviation & 9,50 & 10,0 & 0.82 & 4.85 & 9.72 & 8.88 \\
\hline
\end{tabular}

Figure 4. Molecular imaging and quantitation by MALDI-MSI of triamcinolone acetonide.

(a) Three human donors were analyzed with the Synapt G2-Si. The MALDI-MSI images were normalized with TAA-d 6 . Four blank tissue sections with a spotted 8-point standard curve, six dosed tissues (three incubated in $434.5 \mathrm{ng} / \mu \mathrm{l}$ and three with $43.5 \mathrm{ng} / \mu \mathrm{l}$ TAA) were placed on an ITO slide. (b) For each experiment, a standard curve was obtained and the average intensities of the tissues were extrapolated to obtain the concentrations. (c) Quantification of TAA in three human OA patient explant cartilages treated with TAA. (d) Summary table of triamcinolone acetonide quantitation in different cartilage tissue sections for three different donors. 

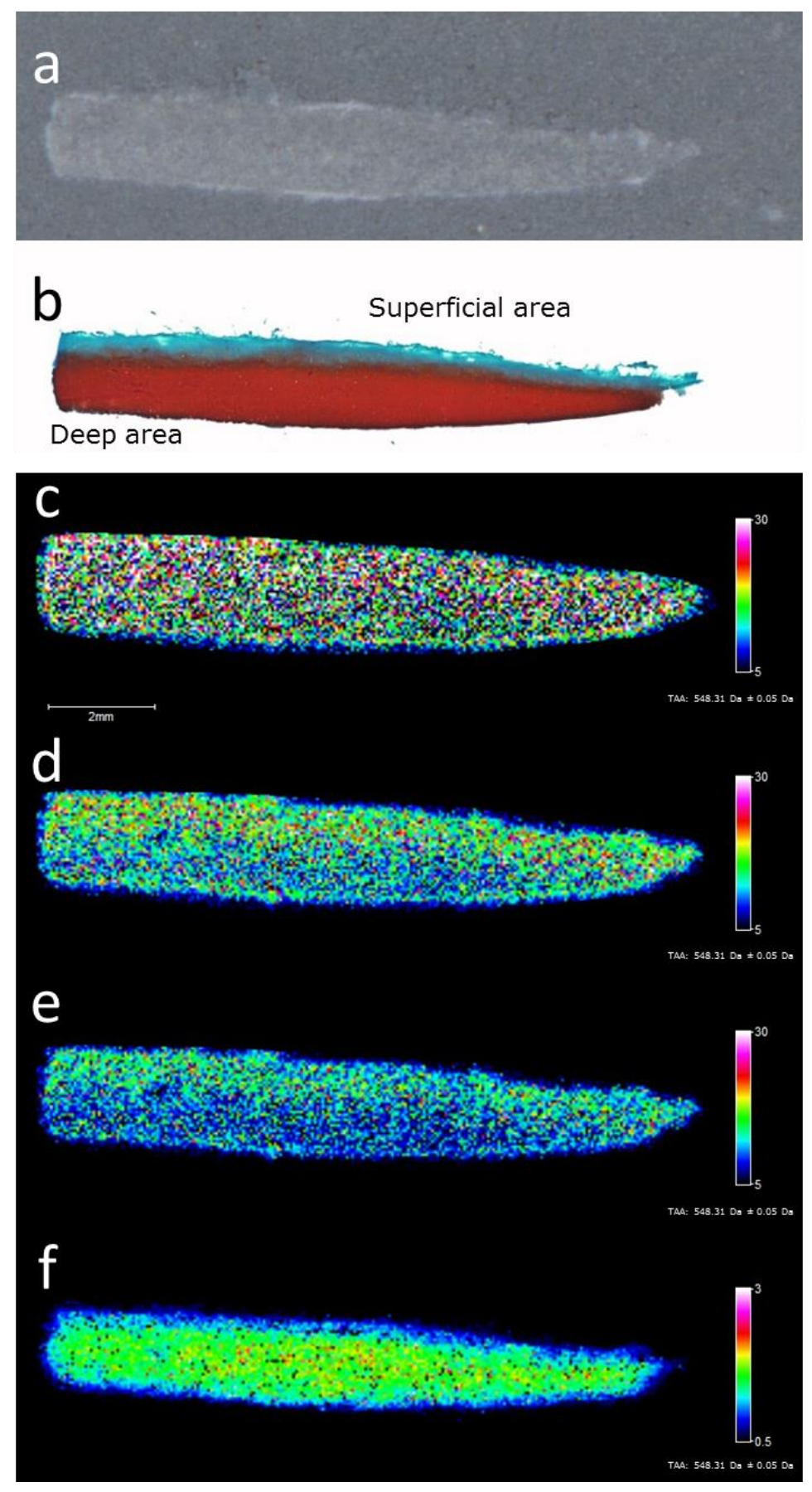

Figure 5. MALDI-MSI distribution of triamcinolone acetonide (TAA) on incubated osteoarthritis cartilage tissue sections using different normalization methods. (a) Digital photographic images of cartilage tissue sections with matrix applied on the tissue before MALDIMSI measurement. (b) The cartilage section was stained to show the different structures of the tissue. The tissue was incubated in a TAA solution $(43.5 \mathrm{ng} / \mu \mathrm{l})$, and the drug distribution can be 
observed using non-normalization (c), median normalization (d), TIC normalization (e), or normalization against the labeled analogue of the drug (f). Only the labeled normalization showed a homogeneous distribution, reducing ion-suppression effects due to spatial heterogeneity of the cartilage.

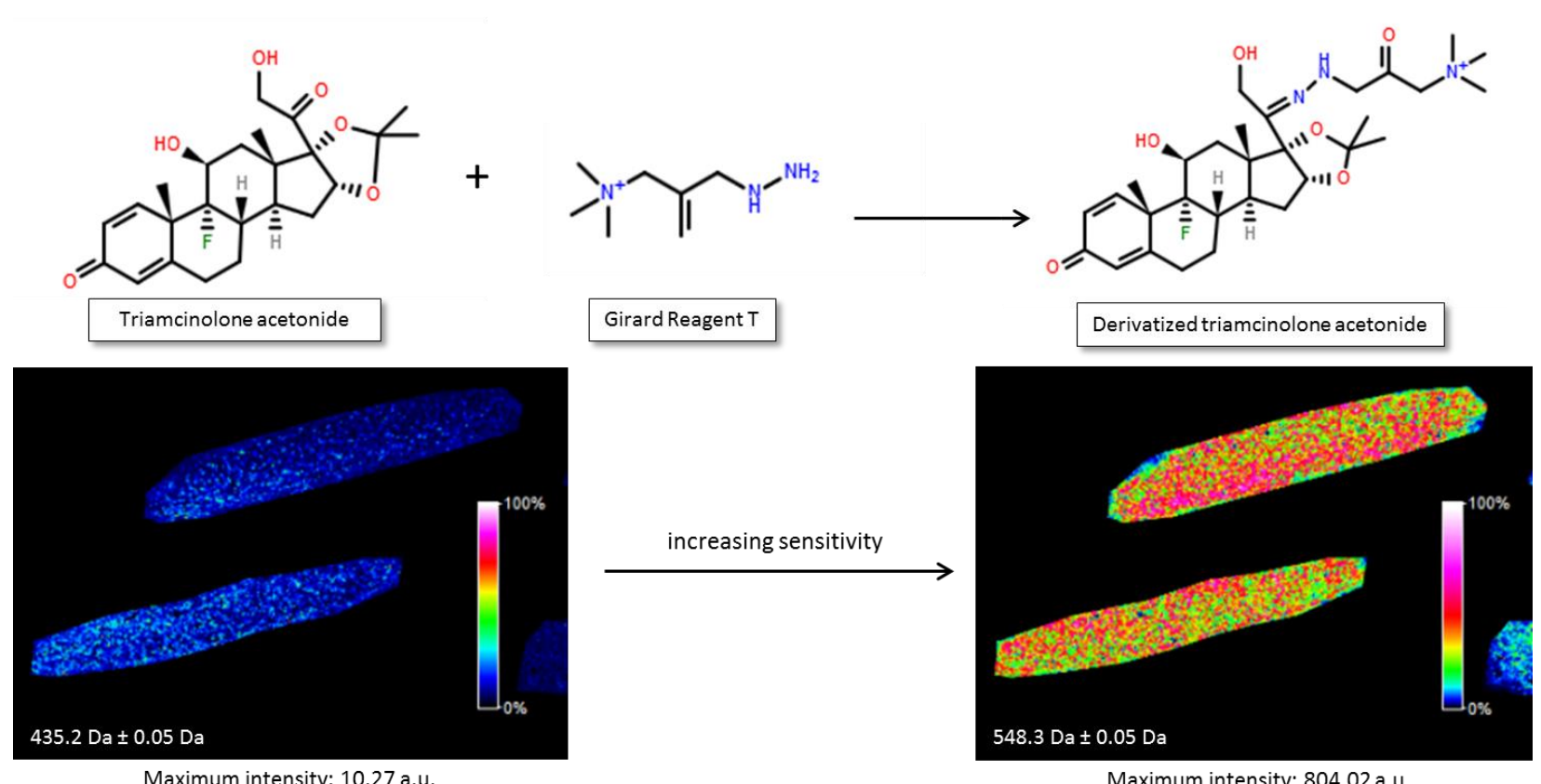

Maximum intensity: 10.27 a.u.

Maximum intensity: 804.02 a.u.

\section{For TOC only}

